\title{
Interactions in local governments' spending decisions: Evidence from Portugal
}

\author{
Hélia Costa \\ European University Institute ${ }^{1}$ \\ Linda Gonçalves Veiga \\ Universidade do Minho and NIPE ${ }^{2}$ \\ Miguel Portela \\ Universidade do Minho, NIPE and IZA Bonn ${ }^{3}$
}

\section{July 2013}

Abstract: This paper aims at analysing the degree of interaction between Portuguese municipalities' expenditure levels by estimating a dynamic panel model, based on jurisdictional reaction functions. The analysis is performed for all 278 Portuguese mainland municipalities from 1986 to 2006, using alternative ways to measure neighbourhood. Results indicate that local governments' spending decisions are significantly, and positively, influenced by the actions of neighbouring municipalities. Attempts to identify the sources of interaction allow us to conclude that they are due to spillovers that require coordination in expenditure items and to mimicking behaviour possibly to attract households and firms.

JEL: C23, H7, R1

Keywords: spending interactions, local government, spatial econometrics, dynamic panel data

\footnotetext{
${ }^{1}$ Address: Villa San Paolo, Via della Piazzuola, 43. 50133 Firenze, Italy. E-mail: helia.costa@eui.eu

2 Address: Universidade do Minho, Escola de Economia e Gestão. 4710-057 Braga, Portugal. E-mail: linda@eeg.uminho.pt.

${ }^{3}$ Address: Universidade do Minho, Escola de Economia e Gestão. 4710-057 Braga, Portugal.

E-mail: mangelo@eeg.uminho.pt.
} 
1. Introduction

Strategic interaction among governments has been a significant matter in public finance and regional science for quite a long time. This paper builds on this literature by investigating if Portuguese local governments' spending decisions influence each other. This is a major issue to understand the distribution of expenditures across municipalities, and the impact of budget decentralization policies. The institutional reforms that Portugal is implementing under the financial assistance program agreed with the IMF and the EU, in May 2011, renders additional relevance to the topic. In order to promote fiscal consolidation, it is important to gain new insights into public policy decisions at the local level.

To our knowledge, interactions between Portuguese local governments have never been investigated. VEIGA and VEIGA, 2007, found strong evidence of strategic manipulation of expenditures' levels and composition by mayors, as more is spent in election years on items that are highly visible to the electorate. They control for transfers received from the central government and for the demographic and political characteristics of the municipalities. However, they did not take into account that the actions of a local government may affect the policy decisions of its neighbours. An important finding of the present paper is that an increase in a municipality's neighbours' expenditures increases its own expenditures due to spillover effects and mimicking behaviour. This is particularly relevant for investment decisions.

Portugal is also an interesting case study because municipalities are all subject to the same rules and legislation, have the same policy instruments and resources at their disposal, and local politicians have some discretionary power over them. Additionally, a large and detailed data set is available (all mainland municipalities from 1986 to 2006), allowing the analysis of spending in specific categories. Furthermore, 
in mainland Portugal there is only one level of local government and, therefore, the estimated magnitude of municipalities' fiscal interaction cannot be attributed to vertical externalities among different levels of authorities, as may occur in many countries that have a multi-tier structure of government.

The paper is organized as follows. The next section presents a brief review of the literature, and section 3 describes the Portuguese institutional framework. In section 4 , the empirical methodology is laid out, and in section 5 the empirical results for the geographical matrices are presented. Finally, section 6 presents the results for alternative weighting matrices and section 7 concludes the paper.

\section{Literature Review}

Interjurisdictional interaction is largely acknowledged in the fiscal federalism literature ${ }^{1}$ and its consequences in terms of policy choices and efficiency have been broadly studied. The empirical literature on strategic interaction between decentralised levels of government is typically divided into three categories: tax and welfare competition, benefit spillovers, and yardstick competition. ${ }^{2}$ The first includes models where a jurisdiction is affected by the choices of other jurisdictions as a result of the existence of a particular resource that they share: the tax-competition literature studies how taxes are chosen strategically when they are levied by governments on a mobile tax base, and that on welfare competition analyses the strategic choices of governments regarding welfare benefit levels, as a result of the mobility of the poor. ${ }^{3}$ Research on spillovers investigates if public expenditure of a jurisdiction generates beneficial or negative effects that spread across its boundaries, affecting the welfare of residents in neighbouring jurisdictions. It tries to assess whether decisions of a local government depend on policies chosen elsewhere. If expenditures refer to local public 
goods that are complementary, such as environmental services or infrastructure and road building, expenditures in neighbouring jurisdictions are likely to boost local governments' own expenditures. However, if local public goods are substitutable (i.e. sports, recreational and schooling facilities) the reverse may occur. Finally, yardstick competition models, often considered to fit the benefit spillover framework, assess how voters, in an asymmetric information setting, use neighbouring jurisdictions' public services and taxes to judge their own government's performance. Not having complete information on the cost of public goods and services, they compare the expenditures and tax levels they face with those most easily observable - those of nearby jurisdictions (Salmon, 1987). ${ }^{4}$

Since the main purpose of this paper is to analyse the extent to which municipalities' spending is influenced by the spending of neighbouring municipalities, and the possible sources of this interdependence, we focus our attention on empirical studies of spillovers. The pioneering work of CASE et al., 1993, formalises a model for the United States, in which a jurisdiction's welfare is assumed to depend, among others, on the public spending in neighbourhood jurisdictions. Neighbour is defined not only in terms of geographic proximity, but also in terms of economic and demographic similarities. Their results provide strong evidence that states' expenditures are significantly influenced by those of their neighbours, in line with theoretical models of benefit spillovers among jurisdictions.

Since CASE et al., 1993, several studies have improved our understanding of how and to what extent spillovers result from local expenditure policies. HANES, 2002, studies Swedish local rescue services and concludes that municipalities respond negatively to benefit spillovers from neighbouring municipalities. Using data for Swiss cantons, SCHALTEGGER and KÜTTEL, 2002, argue that fiscal autonomy and direct 
democracy reduces policy mimicking. REVELLI, 2003, builds up a theoretical framework with horizontal and vertical fiscal externalities in a multi-tier structure of government, in order to assess the source of spatial dependence between English local governments' expenditures. He concludes that, when vertical interaction is accounted for, the magnitude of the horizontal interactions significantly decreases. BAICKER, 2005, uses exogenous shocks to state medical spending in the US to examine the effect of that spending on neighbouring states. She finds substantial spillover effects, and concludes that states are most influenced by neighbouring states from or to which their citizens are most likely to move. SOLÉ-OLLÉ, 2006, presents a framework to analyse and test for two types of expenditure spillovers: benefit spillovers and crowding spillovers, which arise from the crowding of facilities by residents in neighbouring jurisdictions. Estimations of expenditure reaction functions for Spanish local governments reveal that spillovers are stronger in urban areas than in the rest of the country, and that both kinds of spillovers occur in the suburbs, while for the city centres only crowding spillovers are relevant. Focusing on cultural spending of Flemish municipalities, WERCK et al., 2008, find that large municipalities affect their neighbours' behaviour differently from small municipalities. And, finally, ERMINI and SANTOLINI, 2010, confirm the existence of interdependence among local councils' expenditure decisions in Italy, and suggest it may be driven by spillover.

All the above mentioned studies used maximum-likelihood or instrumental variables to address the problem of endogeneity of the expenditure interaction variable, since expenditure in one jurisdiction depends on expenditure in another jurisdiction, but the reverse is also true. Recently, a growing body of research has started to implement the Generalized Method of Moments (GMM) in the context of 
spatial interaction. Using a dynamic panel of European Union countries, REDOANO, 2007, finds evidence of strategic behaviour by central governments on taxes and expenditures. She concludes that: (1) for corporate taxes, European countries follow large countries, while for income and public expenditures, fiscal interactions are driven by yardstick competition; (2) interdependency decreases when countries join the EU. FOUCAULT et al., 2008, test the existence of public spending interactions between French municipalities in a dynamic panel data model. Their results suggest the existence of spending interactions in investment and primary expenditures between neighbouring municipalities and between cities whose mayors have the same partisan affiliation. They find evidence of opportunistic behaviour in pre-electoral periods (ROGOFF and SIBERT, 1988), but not of yardstick competition.

To the best of our knowledge, the Portuguese case has never been investigated. The topic assumes additional relevance because of the sovereign debt crisis that the country is facing. One of the structural reforms agreed by the national authorities with the IMF and the EU in 2011, under the financial assistance program, is to reduce the number of local jurisdictions. Better knowledge on expenditure policy decision-making by local governments is therefore necessary.

\section{Portuguese Institutional Framework}

According to the Portuguese Constitution, there are three types of local governments: parishes (freguesias), municipalities, and administrative regions. However, administrative regions have not yet been implemented in mainland Portugal, due to the rejection of the proposal to institute them in a national referendum, in 1998; there are only two autonomous regions: Azores and Madeira. In the mainland there are currently 278 municipalities, and in the autonomous regions 30 . Our data set does 
not include these 30 overseas municipalities, given the differences in the territorial organization, the fact that inhabitants of the islands may have different needs from those living in continental Europe, and that the status of ultra-peripheral regions allows them to receive additional European Union's funds. We focus our attention on municipalities because freguesias, which are the lowest administrative unit in Portugal, have a very limited scope of functions.

Local governments in Portugal have their own property and finances, and are all subject to the same laws and regulations. Since the reestablishment of democracy in Portugal, in April 1974, there has been a progressive decentralization of competencies from the Central Government to local authorities. Nevertheless, the weight of local governments in general government finances is modest compared to other European Union (EU) countries. The Local Power Law of 1977 (Law 79/77) defined the competencies of municipalities and the division of power among their organs of sovereignty, ${ }^{5}$ emphasising infrastructural interventions, such as the improvement of accessibilities, sewage, and the distribution of water and electricity. In 1984, new legislation (Decree-Law 77/84) was approved enlarging municipalities' competencies to areas such as rural and urban equipment, culture, leisure and sports, transportation and communication, education, and health care. When Portugal joined the European Economic Community, in 1986, the financial situation of municipalities improved considerably, as they started receiving European structural and cohesion funds. Increased resources allowed municipalities to implement several measures that had been delayed due to lack of funds, and to devote greater care to other activities, such as the promotion of culture. Furthermore, more attention was paid to territorial organization and to the establishment of networks with foreign municipalities, namely Spanish jurisdictions near the border. A new law was enacted in 1999 (Law 159/99), 
which extended municipalities' attributions regarding the provision of social and cultural services, urban rehabilitation, protection of the environment, consumer protection, promotion of touristic activities, territorial planning and urbanism, external cooperation, and the attraction of corporate activities. Finally, the current Local Finance Law (Law 2/2007) assigned new responsibilities to municipalities in the areas of education and healthcare, among others.

Municipalities account for the bulk of consolidated expenditures of the local administrations. Municipal public expenditures are divided into capital and current expenditures. The former include investment, their main component, capital transfers to parishes, financial assets and liabilities, and other capital expenditures. Until 2001, investment expenditures included miscellaneous constructions (and subcomponents), acquisition of land, housing, transportation material, machinery and equipment, other buildings (and subcomponents), and other investments. ${ }^{6}$ As for current expenditures, their sub-components are expenditures on goods and services, financial expenditures, human resources, current transfers to parishes, and other current expenditures.

The main sources of municipal revenue are:

- Transfers from the central government. These address both vertical and horizontal imbalances, and include formula based transfers, matching grants (national and EU funds), and others.

- Local taxes: property, property transfer, vehicle and corporate income taxes are the most important. The property tax is the largest own-revenue source of municipalities, who have autonomy to set the tax rates, within a band. Local governments can levy an optional corporate income tax surcharge on taxpayers that operate businesses or have a permanent establishment in the municipal jurisdiction. The rate can vary from 
zero to a maximum defined nationally. Municipalities have little discretionary power over the property transfer and vehicle taxes.

- Other revenues: fees and fines, property income, and financial liabilities, among others.

The decentralization process in Portugal also had a reflection on the importance of each source of revenue. Transfers represented $63 \%$ of local governments' revenues in 1986, but they only account for $43 \%$ in 2006 . On the other hand, the weight of items where the local government has more discretionary power increased. Taxes increased their share on total revenues from $18 \%$ to $33 \%$, and other revenues from $19 \%$ to $24 \%$. The fiscal situation of municipalities has deteriorated markedly in past years, generating fiscal imbalances and the accumulation of debt.

Given that transfers from the central government still represent the main source of municipal revenues; local governments have greater autonomy to establish their expenditure levels and composition than revenues. Therefore, this paper focuses on expenditures to test for interactions between neighbouring municipalities. It is important to note that mayors have greater control over investment expenditures than over current expenditures, since items such as salaries are quite rigid. Furthermore, investment expenditures can be used by local decision makers to attract corporate activity and households, and to gain votes in municipal elections.

\section{Empirical Framework and Econometric Procedure}

The purpose of this paper is to test for strategic interaction in per capita expenditure levels in Portuguese municipalities, and to understand the reasons for its occurrence. If there is interaction, jurisdiction is spending levels depend not only on their own economic and demographic characteristics, but also on the spending levels 
chosen by nearby municipalities. There can be either positive or negative correlation in local public expenditure levels, depending on the effect that the neighbour jurisdictions' expenditures have on the marginal utility of a given municipality's public spending. They will have a positive effect if public goods or services supplied by these neighbours are complements of the municipality's own goods, and a negative effect if they are substitutes. Municipality is reaction function can be described as:

$$
G_{i t}=\beta_{1}+\alpha W G_{i t}+\beta_{2} m u n_{i t}+\varepsilon_{i t}
$$

where $G_{i t}$ is real per capita expenditure in jurisdiction $i$ at time $t ; W G_{i t}$ is a weighted average of neighbouring municipality's real per capita expenditures ( $W$ is a geographical weighted matrix), that is, $W G_{i t}=\sum_{j \neq i} w_{i j t} G_{j t} ; m_{i t}$ is a vector of economic and demographic variables for each jurisdiction, affecting their fiscal choices, and $\varepsilon_{i t}$ is an error term.

The rationale behind this is that citizens may derive benefits from public goods and services provided by their own municipality and by neighbouring municipalities. Thus, a welfare maximizing government will maximize the following objective function:

$$
F\left(G_{i t}, W G_{i t} ; m^{\prime} n_{i t}\right)
$$

Solving the first order condition, a given municipality $i$ will choose $G_{i t}$ according to the reaction function $G_{i t}=R\left(W G_{i t} ; m_{i t}\right)$, which consists of its best response to the decisions of other municipalities, taking into account its own characteristics. If there are no spillovers regarding public expenditures, then $W G_{i t}$ does not enter the reaction function - the coefficient $\alpha$ in equation (1) will be zero.

Since municipalities have a broad range of responsibilities and produce several goods and services, expenditure decisions also involve choosing on which goods and services resources should be allocated. Therefore, we test for interactions on the expenditure level as well as on the composition of expenditures. In a regression 
framework the dependent variable is the logarithm of real per capita expenditures. Several items of expenditure are considered alternatively: total expenditures, capital expenditures, current expenditures, and investment expenditures and its main components.

\subsection{Specification of the weight matrix}

It is highly important to properly select a criterion to define neighbours, given that a misspecification of the weight matrix may lead to inconsistent estimates and affect the coefficients' interpretation (ANSELIN, 1988). The choice of adequate weight matrices is an open discussion within the spatial econometrics literature. Several approaches have been followed to specify the elements of the weight matrix, and no consensus has been achieved on which is better suited for spatial econometric analysis. The matrix has to be specified according to a criterion that reflects previous expectations about the spatial pattern of interaction and, to some extent, reflect economic mechanisms at the base of such interaction. CHESHIRE and MAGRINI, 2009, argue that exhaustive experimentation with the spatial weight matrix is needed. In the discussion that follows we will discuss different weight matrices within our data. Following the trend in the literature, we assume that a municipalitiy is not considered its own neighbour, so the matrix has zero diagonal values.

A commonly used method is to assign weights based on contiguity. ${ }^{7}$ One way to apply this scheme is to assign values of 0 and 1 to the structure of neighbours binary contiguity. This would imply $w_{i j}=1 / m_{i}$ for municipalities $j$ that share a border with municipality $i$, and $w_{i j}=0$ otherwise; where $m_{i}$ is the number of municipalities contiguous to i. Such matrix $\left(W^{9}\right)$, was created for our sample and later used in the 
estimation for total expenditures, as a robustness test. However, as discussed by ANSELIN, 1988, this method does not supply a full representation of the degree of spatial interaction present in the data. It is frequent, after CLIFF and ORD, 1981, to assign different weights to the neighbours, according to the degree to which they affect municipality $i$, so that $\sum_{j} w_{i j}=1$. Different weights may be assigned according to geographical distance, or other variables affecting interactions, namely demographic, economic or political variables.

Following several papers in the literature, we also defined neighbours according to the Euclidean distance between the centres of the municipalities, and constructed the weights as the inverse of this measure. Firstly, and given that Portugal is a relatively small country, all municipalities were considered neighbours $\left(W^{T}\right)$. Secondly, and in order to investigate the robustness of the results, we limited the municipalities that are considered neighbours to those that distance $x$ or less kilometres $\left(W^{x}\right)$, with $x$ $=50$ and $100 \mathrm{~km}$. This is because benefits are more likely to be internalized by municipalities that are closer. In all the specifications the effect of neighbours is smaller the further away they are. The choice of $100 \mathrm{~km}$ was based on the fact that the maximum frequency of distances between Portuguese municipalities is for $100 \mathrm{~km}$, and that of $50 \mathrm{~km}$ was based on the limits generally used in empirical literature on spillovers between local governments. Additionally, $50 \mathrm{~km}$ is the distance from which a journey is considered medium or long distance.

Hence, municipality is expenditures are assumed to be affected by the expenditures of all its neighbours, in inverse proportion to their distances to $i$ and are normalized afterwards, so that $\sum_{j} w_{i j}=1$. Thus, $w_{i j}$ is defined as: 


$$
w_{i j}=\frac{\frac{1}{\text { dist }_{i j}}}{\sum_{j} \frac{1}{\text { dist }_{i j}}} \quad \text { or } \quad w_{i j}=\left\{\begin{array}{l}
\frac{1 / \text { dist }_{i j}}{\sum_{j} / \text { dist }_{i j}} \\
0 \text { otherwise }
\end{array} \text { if } 0<d_{i j} \leq x k m\right.
$$

for the first $\left(W^{\top}\right)$ and second $\left(W^{*}\right)$ specifications, respectively. Hence, each observation $G_{i t}$ is associated to its spatially lagged counterpart, $W G_{i t}=\sum_{j \neq i} w_{i j t} G_{j t}$, which is a linear combination of the observations for all is neighbours.

As a result, four matrices were created: one based on geographical contiguity and three distance decay matrices. Each $W$ is, therefore, a $275 \times 275$ matrix for the period 1986-1998, and a 278x278 matrix, for the period 1999-2006, with zero diagonal elements. ${ }^{8}$ We chose the geographical criterion to compute the weight matrix because benefit spillovers depend on the mobility of the population, which, in turn, depends on the distance between municipalities. ${ }^{9}$

\subsection{Econometric issues}

According to the model, municipality is expenditures in year $t$ depend on municipality js expenditures, and municipality's js expenditures also depend on those of $i$. If municipalities react to each other's spending decisions contemporaneously, then $W G_{j t}$ is endogenous in model (1) and correlated with the contemporaneous error term:

$$
\mathrm{E}\left\{\varepsilon_{i t} W G_{i t}\right\} \neq 0
$$

In this situation, the OLS estimator is biased and inconsistent and there are two possible solutions: Maximum Likelihood and Instrumental Variables. The first solution consists in inverting the system, in order to eliminate the dependent variables from the 
right-hand side of the estimating equation, and using a non-linear optimization routine to estimate the spatial coefficient. Examples of papers using this approach are CASE et al., 1993; BESLEY and CASE, 1995; BRUECKNER, 1998; and FOUCAULT et al., 2008. However, this procedure is computationally demanding, especially with a large dataset with panel observations.

Another possible solution for this problem would be an instrumental variable two-stage least squares (2SLS) procedure, using as instruments the neighbours' variables $\left(m_{u n}\right)$ that influence their fiscal decisions and are not correlated with the error term. Thus, in line with numerous empirical studies, these would be all considered strictly exogenous and would be weighted by $W$. Several papers have used this method successfully, such as KELEJIAN and ROBINSON, 1993; REVELLI, 2002; and SOLÉ-OLLÉ, 2006.

Another empirical problem concerning the estimation of a spatial model is that there may be spatial dependence in the error term, given by:

$$
\varepsilon_{i t}=\lambda W \varepsilon_{i t}+\mu_{i t}
$$

where $\mu_{i t}$ is a white noise error term, uncorrelated between municipalities. If this error correlation is ignored, false evidence of strategic interaction may be provided by the estimation. ML solves this by incorporating this error structure, and IV generates consistent estimates of $\alpha$ even in the presence of spatial error correlation (KELEJIAN and PRUCHA, 1998.

Due to the fact that we are dealing with panel data, we have to consider unobserved heterogeneity. Thus, we augmented equation (1) with an individual municipality effect. Additionally, we included time effects, with year specific intercepts, in order to control for macroeconomic variables that affect all municipalities at the same time. As noted by Case et al., 1993, these are particularly important so that 
spending correlations between jurisdictions caused by common national level shocks are not given spatial significance.

Finally, according to VEIGA and VEIGA, 2007, Portuguese municipalities' level of per capita real expenditures exhibits a high level of persistency. Hence, we also included a lag of the dependent variable, $G_{t-1}$. The model to be tested can, then, be specified as follows:

$$
G_{i t}=\beta_{1}+\gamma G_{i t-1}+\alpha W G_{i t}+\beta_{2} m u n_{i t}+\eta_{i}+\rho_{t}+\varepsilon_{i t}
$$

where $\eta_{i}$ is the individual effect and $\rho_{t}$ are time effects.

Because $G_{t-1}$ was included, by construction it will be correlated with the individual effect, $\eta_{i}$. In order to solve this problem, and following ARELLANO and BOND (1991), we can take first-differences of equation (6) to eliminate $\eta_{i}$ and use as instruments for $\Delta G_{i t-1}$ lagged levels of the dependent variable from two or more periods before - which are not correlated with the residuals in differences, assuming no serial correlation in $\varepsilon_{i t}$. The neighbouring variable, being endogenous, can be instrumented in a similar way. Thus, the estimation may be conducted with instrumental variables, more specifically by the Generalized Method of Moments (as discussed in ARELLANO and BOND, 1991 - GMM - which combines the instruments efficiently. It does so by estimating the model parameters directly from the moment conditions.

However, since we suspect high persistence in expenditures, the use of the System GMM estimation (ARELLANO and BOVER, 1995; BLUNDELL and BOND, 1998) might be the appropriate solution. This extended estimator combines the moment conditions for the model in first differences and for the model in levels, and is especially suitable when there is a high level of persistency in the dependent variable - it is less biased and more precise. It also allows correcting for econometric problems 
such as weak instruments and measurement errors. Given its properties, we will consider this solution throughout our empirical analysis, comparing it, where appropriate, with the OLS, fixed-effects (FE) and GMM applied to first-differences (GMM-Dif) alternatives.

The validity of the instruments later used in our estimations will be checked using the Hansen test for overidentifying restrictions. We will specifically address the presence of heteroskedasticity in our data. Additionally, in each regression, following ARELLANO and BOND, 1991, we will investigate whether the residuals are serially correlated.

Several estimation procedures have been proposed for spatial models, but the only method that incorporates spatial dependence, temporal lags and other endogenous variables is the system GMM estimator (GMM-Sys). ${ }^{10}$ Recently, KUKENOVA and MONTEIRO, 2008, by performing a Monte Carlo Investigation, found the extended GMM to be suitable to estimate dynamic spatial lag models, especially when $\mathrm{N}$ and/or $\mathrm{T}$ are large.

\subsection{Data and empirical model}

The empirical model consists of an equation where municipality i's real per capita expenditure in year $t\left(G_{i t}\right)$, depends on its lagged value, its own characteristics and on the real per capita expenditures of the neighbouring municipalities $\left(G_{j t}\right)$ in the same year. ${ }^{11}$ The following variables are used to capture municipalities' resources and needs:

- grant $_{i t}$ is total real per capita transfers from the central government. Since grants represent the main source of municipalities' revenues, a positive and large coefficient 
is expected. Cap_grant $t_{i t}$ and curr_grant $t_{i t}$ are, respectively, capital grants and current grants. They are included, instead of total grants, in the regressions having as a dependent variable capital, investment and its components, and current expenditures. - popdens $s_{i t}$ represents the population density, in jurisdiction $i$ at time $t$. It proxies for the level of urbanisation and allow us to test for congestion effects or scale economies in the provision of local public goods and services.

- In order to pick up differences in population needs, we consider the dependency ratio $\left(\right.$ depend $\left._{i t}\right)$, which is the proportion of population in the municipality that is under 15 years old and over 65 . These groups of the population demand specific services that are provided by local authorities, such as elementary education and facilities for the elderly.

All variables are expressed in logarithm, except for the population density and the percentage of dependent population, so the results can be interpreted as elasticities.

The data set contains annual data on all Portuguese mainland municipalities, for the years 1986 to 2006 . Given that three municipalities ${ }^{12}$ were only created in 1998, from 1986 to 1998 there are only data for 275 municipalities. Data on municipalities' local accounts were obtained from the Direcção Geral das Autarquias Locais's (DGAL) annual publication Finanças Municipais (Municipal Finances). That on population and consumer price indexes was collected from Marktest's Sales Index (SI) and the proportions of population under 15 and over 65 were collected from the Regional Statistical Yearbook, of the Portuguese Institute of Statistics (INE). Descriptive statistics are presented in Table 1. Portuguese municipalities have an average of 540.28 euros per capita for total expenditures in the period in analysis, with a standard deviation of 317.4 . Current expenditures account for around $51 \%$ of total 
expenditures, with capital expenditures representing the other $49 \%$. Of the latter, about $81 \%$ are investment expenditures.

[Table 1 about here]

5. Results for geographical distance matrices

Empirical results based on geographical proximity are presented in Tables 2 to 4. Our key estimates are discussed in Section 5.1, Table 2, where we estimate equation (6) for Total, Capital, Current, and Investment Expenditures, using $W^{\top}$ as the weighting matrix. In Section 5.2, we test for alternative distance weighting matrices, estimating equation (6) for Total expenditures. Finally, under Section 5.3, we extend our empirical analysis to investment components. Throughout the analysis we implement a similar GMM-Sys strategy, which facilitates the comparison of results obtained for different dependent variables and weighting matrices.

\subsection{Total, Capital, Current, and Investment Expenditures}

Table 2 presents estimation results for total, capital, current and investment real per capita expenditures. For total expenditures, we estimate equation (6) by Ordinary Least Squares (OLS), Fixed Effects (FE) and System Generalized Method of Moments (GMM-Sys) in columns (1) to (6). For the remaining dependent variables, we only estimate the model by GMM-Sys. In order to take into account for the specific dynamics of each dependent variable, we include several lags as explanatory variables. The specific number of lags of the dependent variable in each equation is reported in the note to Table 2. Only the coefficient of the first lag is reported. In all specifications we estimate equation (6) with and without neighbouring expenditures. 
The spatial dependence variable was computed using the matrix $W^{\top}$, which considers all Portuguese municipalities as neighbours, with weights in inverse proportion to the distances between them. For the GMM-Sys we use the two-step estimation with the finite-sample correction for standard errors suggested by WINDMEIJER, 2005. For all specifications we include time specific dummies. The reported statistics are robust to heteroskedasticity and serial correlation in the errors. Since we suspect the errors are non-spherical, we report the Hansen consistent test instead of the Sargan statistic.

For the GMM regressions discussed below, we instrument, for the differenced equations, first-differences of the dependent variable using its levels lagged at least two periods, and its lagged first-differences as instruments for the level equations. Grants and neighbouring municipalities expenditures are assumed to be endogenous, and are instrumented similarly to lagged own expenditures. The argument is that transfers from the central government can be, to some extent, influenced by local governments. Finally, the demographic variables, as well as the time dummies, are assumed as exogenous. We based this belief on the fact that municipalities have little or no control over demographic variables (such as population density and the percentage of people under 15 and over 65 ). Furthermore, any shocks that may affect the entire country, which are controlled for by time dummies, are also exogenous to individual municipalities.

Our first result (OLS, columns (1) and (2), Table 2) indicates that total expenditures show some degree of persistence. Focusing on our key explanatory variable, neighbouring total expenditures, we conclude that there are positive spillover effects across municipalities. When accounting for unobserved municipality specific effects, in columns (3) and (4), we corroborate the results obtained by OLS. Although OLS and FE produce biased estimates, due to the presence of the lagged dependent 
variable on the right hand-side of equation (6), they provide a useful benchmark on what we should expect from the consistent GMM estimates.

[Table 2 about here]

The serial correlation pattern in the first-differenced residuals in models (5) and (6), by showing insignificant AR2 (and AR3), indicates that we need to instrument the equations in first-differences with two lags of the dependent variable, and firstdifferences lagged one period for the equations in levels. Additionally, we restrict the instruments for first-differences equations to five lags. In order to limit the number of instruments, we do not apply each moment condition underlying the system-GMM procedure to each time period and lag available. Instead, we apply a single moment condition for each period and regressor. ${ }^{13}$

By estimating our model using the GMM system procedure we confirm that total expenditures exhibit some persistence, revealed by the estimated coefficient of 0.41 for lag total expenditures, which is statistically significant at the $1 \%$ level - column (6). This might result from the fact that municipalities' spending decisions are highly dependent on their resources and on their population needs, which are also persistent over time. The exclusion of neighbouring total expenditures, column (5), does not significantly alter the level of persistency in the series.

Focusing on column (6), we conclude that the elasticity of own expenditures with respect to neighbouring total expenditures is significant and about 0.48: a one percent increase in neighbours' expenditures is associated with an increase in own expenditures of about $0.48 \%$, confirming the existence of complementary characteristics of local public goods provided by neighbouring municipalities or mimicking effects. This result clearly indicates that total expenditures spill over municipalities; i.e., own expenditures vary positively with neighbours' decisions 
regarding this variable. There is strong evidence in favour of expenditure interactions among Portuguese municipalities - the variable $W G_{j t}$ is statistically significant and positively signed. Grants are statistically significant with a large positive coefficient, derived from the fact that transfers from the central government are municipalities' main source of revenue. The density of the population exerts a positive and statistically significant effect on total expenditures, suggesting the existence of congestion effects in the provision of local public goods and services. Contrary to our priors, the share of dependent population does not seem to influence total expenditures. Given the persistency of the series, and the inclusion of several lags of the dependent variables as explanatory variables, ${ }^{14}$ it is not surprising that the demographic variables, which are quite stable over time, do not exert a large impact.

The tests for serial correlation in the error term reveal, as expected, negative serial correlation in first-differences, which disappears for second and higher orders. This result follows from the formulation of equation (6), and constitutes a first validation of the instruments used. The Hansen test's statistic is 10.13 , has 9 degrees of freedom, and an associated $p$-value of 0.34 . This result validates the instrument set used in the estimation of column (6). A similar conclusion is valid for the estimates presented in column (5).

Moving to capital expenditures, Table 2, columns (7) and (8), the estimated coefficient for the lagged dependent variable is slightly smaller than the one estimated for total expenditures. Previous results extend to capital expenditures; i.e., capital expenditures are positively determined by grants. The information conveyed by the serial correlation tests, $A R(1)$ to $A R(3)$, together with the Hansen test, validate de instruments used in our regressions. For both estimations, columns (7) and (8), the pvalue of the Hansen test is bounded between 0.18 and 0.40 , and the serial correlation 
in first-differenced residuals disappears after two lags. The estimated coefficient associated with capital expenditures of neighbouring municipalities is statistically significant, and has increased considerably, indicating an elasticity of 0.69. Grants continue to exert a positive and statistically significant influence on capital expenditures.

Moving to current expenditures, column (10) reveals a different pattern in terms of residual serial correlation. As we can see in the AR tests, residual's serial correlation only disappears after 3 lags. This implies that in the instrument set we use current expenditures lagged three to five periods for first-differences equations, and first-differences of current expenditures lagged two periods for equations in levels. The remaining variables are instrumented as discussed above. Focusing our attention on column (10), the model with neighbouring current expenditures, we now observe that there are spillovers of this item across municipalities: a 10\% increase in neighbours' expenditures brings about a $5.7 \%$ increase in own current expenditures. Persistence is now much higher, when compared to the previous expenditure variables. This is consistent with the economic theory, since local governments may not be able to make sudden changes in their fiscal choices, either because they have too high adjustment costs or because they are blocked by law, namely regarding the wage policy and firing decisions. ${ }^{15}$ This is particularly true for current expenditures, which are usually set in advance for several years and are not easily changeable. Furthermore, grants and the demographic variables, although correctly signed, seem to have a smaller impact when compared to the previous two items. Overall, estimations under columns (9) and (10) are validated by the serial correlation and Hansen tests. ${ }^{16}$ 
Finally, investment expenditures, which represent the bulk of capital expenditures (around 80\%), reveal significant and large overall investment spillovers from neighbouring expenditures, with an elasticity of 0.86 . There is also evidence that investment decisions depend on resources available. As before, the instrument set is validated. Given the relevance of this sort of expenditures we will discuss the spillovers for different investment components in Section 5.3.

\subsection{Alternative weighting matrices}

In order to test the robustness of the results regarding the use of the weighting matrix, we will now implement our analysis using three alternative weighting matrices described in section 4.1: binary/contiguity $\left(W^{0}\right), 50 \mathrm{kms}\left(W^{50}\right)$, and $100 \mathrm{kms}\left(W^{100}\right)$. The results are shown in Table 3. Columns (1) to (3) present distance decay results considering the contiguity matrix, while columns (4) and (5) consider $50 \mathrm{~km}$ and $100 \mathrm{~km}$, respectively, as the maximum distance after which weights are set to zero. The standardized binary/contiguity matrix ( $\left.W^{0}\right)$ assigns the value 1 to municipalities that share a border and 0 otherwise. Throughout this section we only consider total expenditures as our dependent variable.

[Table 3 about here]

Not accounting for specific effects - Table 3, column (1) - the elasticity of own expenditures to neighbouring total expenditures is quite small (0.09). However, this result is biased, as we ignore both the fixed unobserved effects and the lagged dependent variable. The inclusion of municipalities' fixed effects (column 2) increases the degree to which local governments react to their neighbours expenditure decisions. However, this result is still biased, as the within transformed lagged dependent variable is correlated with the within transformed error term. In order to 
solve the bias, and to render our results more comparable to those presented in the previous section, we implement the system GMM-Sys estimation ${ }^{17}$ (column 3 ) and the results clearly indicate the presence of neighbouring spillover effects. Analysing the results shown in columns (4) and (5), both estimated by GMM-Sys, not only do we reinforce the conclusion that there are spillovers of total expenditures between neighbours, but also that their size is determined by the weighting matrix we use. It is clear from our results that, when allowing for a broader definition of neighbourhood, we capture a higher effect of neighbours' expenditures. Under the definition of $100 \mathrm{~km}$ neighbourhood, we estimate an elasticity of 0.41 (Table 3 , column 5), while considering $50 \mathrm{~km}$ neighbourhood (Table 3 , column 5 ), we estimate such elasticity to be of about 0.33 . This is understandable, given that the latter definition of neighbourhood is more restrictive. The remaining results are similar for all regressions.

This set of results corroborates and strengthens the discussion and the options made in Section 5.1. As such, we conclude that there is strategic interaction regarding Portuguese municipalities' total expenditure levels.

\subsection{Components of Investment Expenditures}

There is no reason to assume that patterns of expenditure interdependence are the same for all categories of investment. It is possible that some types of spending exert complementarity and others substitutability, cancelling each other out and reducing the aggregate effect. An analysis of aggregate spending levels might bias downward the effects of spillovers on spending. To investigate this possibility, the 
model defined in equation (6), and discussed in Section 5.1, is now implemented for the sub-components of investment expenditures.

Until 2001, investment expenditures had seven main categories: (1) Acquisition of Land, (2) Housing, (3) Transportation Material, (4) Machinery and Equipment; (5) Miscellaneous Constructions; (6) Other Buildings, and (7) Other Investments. Miscellaneous Constructions and Other Buildings were de-composed in, respectively, six and three subcomponents. When analysing the data set we realized that some of these items have a significant number of zeros and missing values, which led us to exclude some of them from the analysis. ${ }^{18}$ Table 4 shows the results for 11 of the 16 components and subcomponents of investment expenditures. In this table, we only report the estimated coefficient for $W G_{i t}$ and its standard error. Additionally, for the GMM type regressions we report the statistic for the Hansen test, and its degrees of freedom. ${ }^{19}$ We report estimation results obtained when using the matrix $W^{T}$, that is, the matrix that considers all municipalities as neighbours. The instrument set associated within each GMM regression is similar to the one discussed in Section 5.1 for investment expenditures. In order to keep the regressions as comparable as possible, we use the same structure to define the instruments, particularly in what concerns exogeneity/endogeneity, and the lags used for the instruments are the minimum required to validate the estimates. For each investment component we report the OLS, FE, and GMM-Sys estimates.

[Table 4 about here]

When using the system-GMM procedure, there is evidence of positive spillovers across the border for Machinery and equipment, Miscellaneous Constructions (particularly for Sewage, Rural Roads, and Other miscellaneous constructions), and for two items of Other Buildings (Sports, recreational and 
schooling facilities and Other expenditures). As before, the instrument set is validated by the serial correlation and overidentification tests. The significant coefficient for the spatial interaction variable associated with Rural roads may be due to coordination among neighbouring municipalities. Roads frequently cross the borders of several jurisdictions, implying that improvements or extensions in one jurisdiction may require complementary investments from neighbouring municipalities. The same reasoning applies to sewage networks. Regarding other items, such as investments in sports, recreational and schooling facilities, the positive strategic interaction is likely to be due to mimicking of nearby municipalities, since some expenditures may be used to attract households and firms, in line with the tax and welfare competition literature. Mimicking might also occur for political reasons, if it occurs more in election years or between mayors of similar political orientation, or due to similarities in the population's needs, if it occurs more between jurisdictions that are similar in demographic terms.

\section{Additional sources of fiscal interactions}

In order to disentangle the sources of fiscal interactions among jurisdictions, we perform several additional empirical tests. We start by interacting the variable measuring the weighted average of neighbouring municipalities' expenditures with a series of dummy variables for electoral years or which characterise municipalities. Second, we test alternative weighting matrices based on population density and mayors' ideology.

According to the yardstick competition hypothesis, local jurisdictions react more to their neighbours' fiscal policies during electoral periods because voters compare the mayors' performances. To test this prediction, a dummy variable was created (Mun Election $_{\text {it) }}$ for municipal election years. The dummy was then interacted with the 
variable representing the weighted average of neighbouring municipalities' expenditures $\left(W G_{i t}\right)$. We find no evidence of yardstick competition in the main expenditure items. Table 5 presents the results for Total, Capital, Current and Investment Expenditure. All regressions include the same set of control variables as those of the previous tables but, in order to economize space, only the estimated coefficients associated with $G_{i t-1}, W G_{i t}$, and its interactions with the electoral dummy are presented. We cannot include the dummy for municipal elections in the regression because we control for time effects with year dummies, and the former would be a linear combination of latter dummies. We also run the regressions using investment sub-components as dependent variables, but results are not consistent with larger interactions during electoral years.

\section{[Table 5 about here]}

In order to investigate other sources of political influences, we also test if interactions depend on whether the mayor belongs or not to the Prime-Minister's party, on her right or left-wing orientation, on whether the mayors' party has a majority or not in the municipal assembly and, finally, whether municipal/legislative elections were a close race or not. To test the latter effect for municipal election results, two dummy variables were created: one takes the value of one when the difference in the vote shares of the mayors' party and that of her main opponent was less than five percentage points in the last election; and another dummy for larger differences in vote shares. Empirical results never indicate statistically significant differences in the degree of strategic interaction among municipalities. ${ }^{20}$

Following SCHALTEGGER and KÜTTEL, 2002, we investigate if municipalities with larger fiscal autonomy, that is, those that depend less on central government transfers, take their expenditure decisions more independently than the others. 
Empirical results do not confirm this hypothesis. Because municipalities constituting the capital of a district could play a leading role and have different expenditure needs, we include a dummy to signal them and interact it with $W G_{i t .}$ No evidence is found that they react differently to expenditures of nearby municipalities.

As put by CHESHIRE and MAGRINI, 2009, there is no a priori basis for selecting distance weights. So, besides the geographical definitions of neighbourhood described in the previous sub-section, we use other concepts based on population density and mayors' ideology. Municipalities with similar population density may have a greater tendency to mimic each other's behaviour. To test this hypothesis, weights are defined in the following way:

$$
w_{i t}^{\text {PD }}=\frac{1 / \mid \text { Dens }_{i t}-\text { Dens }_{j t} \mid}{\sum_{j} / / \text { Dens }_{i t}-\text { Dens }_{j t} \mid} \quad \text {, with } \mathbf{j} \neq \mathbf{i} \text {. }
$$

The results presented in Table 6 reveal that, of the four expenditure items used as dependent variables, the variable capturing average expenditure by neighbouring jurisdictions is only statistically significant for investment expenditures. ${ }^{21}$ The estimated coefficient (0.33) is smaller than the one reported in column 12 of Table 2, but it still suggests that municipalities react to their neighbours' expenditures. On what concerns investment decisions, municipalities seem to imitate those with similar population density. All regressions include the same set of control variables as those presented in table 2 but, in order to economize space, only the estimated coefficients associated with $G_{i t-1}$ and $W^{P D} G_{i t}$ are presented.

\section{[Table 6 about here]}

We also investigate if political ideology similarity between local governments increases mimicking in policy resolutions, because of similar preferences and larger 
sharing of ideas among politicians. To test this hypothesis, mayors were classified as right or left-wing oriented. Two political weighting matrices were defined. One matrix $\left(W^{S P}\right)$ assigns a weight of $1 / s_{i t}$ when municipalities $i$ and $j$ are ruled by mayors with the same political affiliation at time $t$, and zero otherwise. $s_{i t}$ is the total number of municipalities that are governed by a mayor belonging to the party in office in municipality $i$ at time $t$. The other matrix is $1-W^{S P}$. Both matrices have zero diagonals. We then multiply these matrices by the inverse distance matrix, and normalize the weights to one. We intended to include the two series obtained, for the average expenditure of neighbours of the same political colour and for neighbours of different political colour in the regression and test for the equality of estimated coefficients. However, the two series turned out to be highly correlated and could not be included simultaneously in the same regression. For total expenditures the correlation is $96.6 \%$. This is not surprising, since VEIGA and VEIGA, 2007, found that mayors' ideology does not play a significant role in per capita local governments' expenditure decisions.

\section{Conclusion}

The paper aims at understanding the driving forces of interactions in Portuguese municipalities' expenditure levels. A dynamic panel data model is estimated based on jurisdictional reaction functions. The analysis was performed for all 278 Portuguese mainland municipalities from 1986 to 2006. Given the persistence of the expenditure series, estimations were performed by system-GMM using alternative ways to measure geographical neighbourhood. The empirical results allow us to conclude that local governments do not make their spending decisions in isolation; they are significantly influenced by the actions of neighbouring municipalities. For total expenditures, there is evidence that a $10 \%$ increase in nearby 
municipalities' expenditures increases expenditures in a given municipality by $4.8 \%$, on average. For current and, especially for capital expenditures, the effect is also visible at the aggregate level. Results also support the existence of strong spillovers for investment expenditures, and for the sub-components Machinery and Equipment; Sports, recreational and schooling facilities and expenditures on constructions that require coordination among neighbouring municipalities.

In order to disentangle the sources of interaction, we use alternative weighting matrices to geographic proximity that take into account similarity in population density and political party similarity of the mayors. Only for investment expenditures does population density seem to be a driving force of spatial interactions among local governments. Similarity, politicians' ideology does not seem to generate copycat effects. We also test for yardstick competition and for differences in interactions among municipalities resulting from mayors' political characteristics (belonging to the Prime-Minister's party, being right-wing oriented, or having a majority in the municipal assembly), from whether municipalities are a district capital or not, and whether the last municipal election was a close race or not. Results allow us to reject these hypotheses. Portuguese municipalities react to each other's expenditures due to spillovers that require coordination in expenditure items and to mimicking behaviour of the others, possibly with the purpose of attracting households and firms.

\section{Acknowledgements}

The authors thank very useful comments from Francisco Veiga, and two anonymous referees. They acknowledge the financial support provided by the European Regional Development Fund, through the Operational Program Factors of Competitiveness COMPETE, and by national funds received through FCT - Portuguese Foundation for 
Science and Technology, under research grants PTDC/ECO/65711/2006 and PTDC/EGE-ECO/118501/2010. 


\section{Notes}

${ }^{1}$ See OATES, 1999, for a survey. BRUECKNER, 2003, and REVELLI, 2006a, survey the empirical research on strategic interaction among local governments.

${ }^{2}$ An exception is ALLERS and ELHORST, 2011, that studies fiscal policy interactions in Dutch municipalities, in an integrated way. They estimate a system of simultaneous equations for expenditures and taxes, taking into account differences in spending needs between jurisdictions. They argue that in single equation models the degree of interaction is estimated inefficiently.

${ }^{3}$ Examples of the latter include BRUECKNER, 1998; SAAVEDRA, 2000; ALLERS and ELHORST, 2005; FIVA and RATTSO, 2006; REVELLI, 2006a; REDOANO, 2007.

${ }^{4}$ BESLEY and CASE, 1995, present empirical evidence of yardstick competition using US state data. For European countries refer to BORDIGNON et al., 2003; SOLLÉ-OLLÉ, 2003; ALLERS and ELHORST, 2005; REVELLI, 2006b, and REDOANO, 2007. CALDEIRA, 2012, analyses the Chinese case.

${ }^{5}$ Legislative power in municipalities belongs to the Municipal Assembly, while the executive power rests with the Town Council, where the mayor has a prominent role.

${ }^{6}$ In 2002, investment accounts were reorganized into the following categories: acquisition of land, buildings and other constructions (and subcomponents), transportation material, machinery and equipment and, finally, others.

${ }^{7}$ See BESLEY and CASE, 1995.

${ }^{8}$ Three municipalities were created in 1998: Trofa, Odivelas and Vizela.

${ }^{9}$ An alternative way to measure municipalities' interaction would be to use economic flows across regions. However, the data is not readily available for our analysis.

${ }^{10}$ For a description of estimators dealing with spatial and time dependence in panel datasets see KUKENOVA and MONTEIRO, 2008.

${ }^{11}$ In preliminary analysis we tested for strategic interaction over time, but additional lags of weighted expenditures by neighboring municipalities never turned out as statistically significant.

${ }^{12}$ Odivelas, Trofa and Vizela.

${ }^{13}$ The model has been estimated with Stata's command XTABOND2, and the option 'collapse' has been used to define the instruments for $G_{i t-1}$, Grant and Taxes. 
${ }^{14}$ The choice of the number of lags to include was based on the specific dynamics of the dependent variable, as well as on their statistical significance.

${ }^{15}$ Expenditures with employees represent around $50 \%$ of current expenditures.

${ }^{16}$ We do not restrict the number of instruments when defining the set of instruments for neighboring Current Expenditures, column (10), which explains the high number of instruments used in this regression.

${ }^{17}$ Hansen tests indicate that, for our data, the system-GMM is preferable to the GMM that only includes the first-differenced equations.

${ }^{18}$ Acquisition of land, Housing, Infrastructures on solid waste treatment, Social equipment, and Other investments were excluded because they all have an average of more than 50 missing values or zeros per year.

${ }^{19}$ Results for the entire regressions are available from the authors upon request.

${ }^{20}$ These results are not shown in the paper but are available from the authors upon request.

${ }^{21}$ This result, however, is not confirmed when using the fixed effects estimation procedure. 
References

ALLERS M. A. and ELHORST J. P. (2005) Tax mimicking and yardstick competition among local governments in the Netherlands, International Tax and Public Finance 12, 493-513.

ALLERS M. A. and ELHORST J. P. (2011) A simultaneous equations model of fiscal policy interactions, Journal of Regional Science 51(2), 271-291.

ANSELIN L. (1988) Spatial econometrics: methods and models. Dordrecht: Kluwer.

ARELLANO M. and BOND S. R. (1991) Some tests of specification for panel data: Monte Carlo evidence and an application to employment equation, Review of Economic Studies 58, 277-297.

ARELLANO M. and BOVER O. (1995) Another look at the instrumental variable estimation of error-components models, Journal of Econometrics 68, 29-52.

BESLEY T. and CASE A. (1995) Incumbent behaviour: vote seeking, tax setting and yardstick competition, American Economic Review 85(1), 25-45.

BAICKER K. (2005) The spillover effects of state spending, Journal of Public Economics 89, 529-544.

BLUNDELL R. W. and BOND S. R. (1998) Initial conditions and moment restrictions in dynamic panel data models, Journal of Econometrics 87, 115-143.

BORDIGNON, M. CERNIGLIA, F AND REVELLI, F. (2003) In search of yardstick competition: a spatial analysis of Italian municipality property setting, Journal of Urban Economics 54, 199-217.

BRUECKNER J. K. (1998) Testing for strategic interaction among local governments: the case of growth controls, Journal of Urban Economics 44, 438467. 
BRUECKNER J. K. (2003) Strategic interaction among governments: an overview of empirical studies, International Regional Science Review 26, 175-188.

CALDEIRA, E. (2012) Yardstick competition in a federation: Theory and evidence from China, China Economic Review 23, 878-897.

CASE, A. C. ROSEN H. S. and HINES J. R. (1993) Budget spillovers and fiscal policy interdependence: evidence from the states, Journal of Public Economics $52,285-307$.

CHESHIRE, P. and S. MAGRINI (2009) Urban growth drivers in a Europe of sticky people and implicit boundaries, Journal of Economic Geography, 9, 85-115.

CLIFF A. and ORD J. K. (1981) Spatial processes: models and applications. London: Pion.

DIREÇÃO GERAL AS AUTARQUIAS LOCAIS (1986-2006) Finanças Municipais, Direção Geral das Autarquias Locais, Lisbon.

ERMINI, B. and SANTOLINI, R. (2010) Local expenditure interaction in Italian municipalities: do local partnerships make a difference? Local Government Studies 36(5), 655-677.

FIVA J. and RATTSO J. (2006) Welfare competition in Norway: norms and expenditures. European, Journal of Political Economy 22, 202- 222.

FOUCAULT M., MADIES T. and PATY S. (2008) Public spending interactions and local politics. Empirical evidence from French municipalities, Public Choice 137(1), 57-80.

HANES N. (2002) Spatial spillover effects in the Swedish local rescue services, Regional Studies 36, 531-539. 
HOLL H. (2004) Manufacturing location and impacts of road transport infrastructure: empirical evidence from Spain, Regional Science and Urban Economics 34(3), 341-363.

INSTITUTO NACIONAL DE ESTATÍSTICA (1986-2006) Regional Statistical Yearbook. INE.

KELEJIAN H. H. and PRUCHA I. (1998) A generalized spatial two stage least squares procedures for estimating a spatial autoregressive model with autoregressive disturbances, Journal of Real Estate Finance and Economics 17, $99-121$.

KELEJIAN H. H. and ROBINSON D. P. (1993) A suggested method of estimation for spatial interdependent models with autocorrelated errors, and an application to a county expenditure model, Papers in Regional Science 72, 297-312.

KUKENOVA M. and MONTEIRO J. (2008) Spatial dynamic panel model and system GMM: A Monte Carlo Investigation. MPRA Paper No. 11569.

LUNDBERG J. (2006) Spatial interaction model of spillovers from locally provided public services, Regional Studies 40(6), 631 - 644 .

MARKTEST (2009) Sales Index. Marktest Consulting.

OATES W. (1999) An essay on fiscal federalism, Journal of Economic Literature $37(3), 1120-1149$.

REDOANO M. (2007) Fiscal interactions among European countries. Does the EU matter? CESIFO Working paper No. 1952.

REVELLI F. (2002) Testing the tax mimicking versus expenditure spill-over hypotheses using English data, Applied economics 34(14), 1723-1731

REVELLI F. (2003) Reaction or interaction? Spatial process identification in multitiered government structures, Journal of Urban Economics 53(1), 29-53. 
REVELLI F. (2005) On spatial public finance empirics, International Tax and Public Finance 12, 475-492.

REVELLI, F. (2006a) Spatial interaction among governments. In: E. Ahmad \& G. Brosio (Eds) Handbook in Fiscal Federalism (Cheltenham: Edward Elgar).

REVELLI, F. (2006b) Performance rating and yardstick competition in social service provision, Journal of Public Economics 90, 459-475.

ROGOFF K. and Sibert A. (1988) Elections and macroeconomic policy cycles, Review of Economics Studies 55, 1-16.

SAAVEDRA L. (2000) A model of welfare competition with evidence from AFDC, Journal of Urban Economics 47, 248-279.

SALMON, P. (1987) Decentralization as an incentive scheme, Oxford Review of Economic Policy 3, 24-43.

SCHALTEGGER, C. and KÜTTEL, D. (2002) Exit, voice, mimicking behavior: Evidence from Swiss cantons, Public Choice 113, 1-23.

SOLÉ-OLLÉ A. (2003) Electoral accountability and tax mimicking: The effects of electoral margins, coalition government, and ideology, European Journal of Political Economy, 19 685-713.

SOLÉ-OLLÉ A. (2006) Expenditure spillovers and fiscal interactions: empirical evidence from local governments in Spain, Journal of Urban Economics 59, 32 53.

VEIGA L. G. and VEIGA F. J. (2007) Political business cycles at the municipal level, Public Choice 131(1-2), 45-64.

WERCK, K., HEYNDELS, B. and GEYS, B. (2008) The impact of 'central places' on spatial spending patterns: evidence from Flemish local government cultural expenditures, Journal of Cultural Economics 32: 35-58. 
WINDMEIJER F. (2005) A finite sample correction for the variance of linear two-step GMM estimators, Journal of Econometrics 126(1), 25-51. 
Table 1 - Descriptive statistics

\begin{tabular}{lccccc}
\hline & No Obs. & Mean & Stand. Dev. & Min & Max \\
\hline Total Expenditures & 5791 & 540.28 & 317.40 & 72.05 & 2315.13 \\
Current Expenditures & 5791 & 277.76 & 170.40 & 41.45 & 1471.92 \\
Capital Expenditures & 5791 & 262.50 & 179.20 & 13.48 & 1620.73 \\
Investment Expenditures & 5791 & 213.71 & 156.37 & 10.08 & 1359.76 \\
$\quad$ Acquisition of land Expenditures & 3460 & 7.57 & 12.62 & 0.0007 & 233.23 \\
Housing Expenditures & 3009 & 15.67 & 31.29 & 0.0002 & 394.90 \\
Transportation material Expenditures & 3998 & 6.41 & 7.78 & 0.008 & 88.99 \\
Machinery and equipment Expenditures & 4359 & 11.86 & 11.48 & 0.009 & 146.35 \\
Miscellaneous constructions Expenditures & 4398 & 127.85 & 113.04 & 0.07 & 1810.72 \\
$\quad$ Overpasses, streets and complementary works Expenditures & 4230 & 31.11 & 38.01 & 0.0004 & 479.11 \\
$\quad$ Sewage Expenditures & 3761 & 16.50 & 23.98 & 0.002 & 393.37 \\
$\quad$ Water treatment and distribution Expenditures & 3726 & 19.63 & 29.42 & 0.001 & 570.88 \\
$\quad$ Rural roads Expenditures & 3783 & 43.88 & 57.64 & 0.003 & 772.90 \\
$\quad$ Infrastructures and solid waste treatment Expenditures & 1074 & 5.09 & 23.44 & 0.0001 & 561.10 \\
$\quad$ Other Miscellaneous Constructions Expenditures & 4061 & 25.70 & 44.23 & 0.003 & 705.72 \\
Other buildings Expenditures & 4393 & 34.02 & 38.61 & 0.02 & 531.77 \\
$\quad$ Sports, recreational and schooling facilities Expenditures & 3951 & 14.55 & 24.64 & 0.001 & 361.29 \\
$\quad$ Social equipment Expenditures & 1597 & 6.27 & 13.28 & 0.0003 & 237.66 \\
Other Expenditures in Other Buildings & 4319 & 18.94 & 28.06 & 0.001 & 349.35 \\
Other investments Expenditures & 2063 & 6.60 & 13.33 & 0.0003 & 191.87 \\
Total Grants & 5791 & 356.42 & 255.85 & 46.68 & 1988.24 \\
Capital Grants & 5790 & 187.91 & 141.14 & 18.02 & 1374.26 \\
Current Grants & 5791 & 168.54 & 124.34 & 27.53 & 979.14 \\
Population (number of inhabitants) & 5799 & 34827 & 57972 & 1767 & 727500 \\
Population Density (inhabitants per km) & 5799 & 2.91 & 8.68 & 0.06 & 86.76 \\
Share of Dependent Population (\%) & 5799 & 35.88 & 4.14 & 17.10 & 58.19 \\
\hline \hline
\end{tabular}

Sources: INE, DGAL, SI (several years).

Notes: Monetary values are expressed in real and per capita terms. The sample period goes from 1986 to 2006, except for investment expenditures subcomponents, for which the period has been restricted to 2001 . 
Table 2 - Estimation results for Total, Capital, Current and Investment Expenditures

\begin{tabular}{|c|c|c|c|c|c|c|c|c|c|c|c|c|}
\hline & $(1)$ & (2) & (3) & $(4)$ & (5) & (6) & (7) & $(8)$ & (9) & $(10)$ & $(11)$ & (12) \\
\hline $\begin{array}{l}\text { D. Variable } \\
\text { Model }\end{array}$ & $\begin{array}{c}\text { TotExp } \\
\text { OLS }\end{array}$ & $\begin{array}{c}\text { TotExp } \\
\text { OLS }\end{array}$ & $\begin{array}{c}\text { TotExp } \\
\text { FE }\end{array}$ & $\begin{array}{c}\text { TotExp } \\
\text { FE }\end{array}$ & $\begin{array}{c}\text { TotExp } \\
\text { GMM-Sys } \\
\end{array}$ & $\begin{array}{c}\text { TotExp } \\
\text { GMM-Sys } \\
\end{array}$ & $\begin{array}{r}\text { CapExp } \\
\text { GMM-Sys } \\
\end{array}$ & $\begin{array}{c}\text { CapExp } \\
\text { GMM-Sys } \\
\end{array}$ & $\begin{array}{c}\text { CurExp } \\
\text { GMM-Sys } \\
\end{array}$ & $\begin{array}{c}\text { CurExp } \\
\text { GMM-Sys } \\
\end{array}$ & $\begin{array}{c}\text { InvExp } \\
\text { GMM-Sys } \\
\end{array}$ & $\begin{array}{c}\text { InvExp } \\
\text { GMM-Sys }\end{array}$ \\
\hline$W G_{i t}$ & $\begin{array}{c}0.69^{* * *} \\
(0.03)\end{array}$ & $\begin{array}{c}0.64^{\star * *} \\
(0.03) \\
0.33^{\star \star \star} \\
(0.05)\end{array}$ & $\begin{array}{c}0.31^{* * *} \\
(0.02)\end{array}$ & $\begin{array}{c}0.30^{\star * *} \\
(0.02) \\
0.48^{\star * \star} \\
(0.10)\end{array}$ & $\begin{array}{c}0.42^{* * *} \\
(0.05)\end{array}$ & $\begin{array}{c}0.41^{* * *} \\
(0.04) \\
0.48^{* *} \\
(0.24)\end{array}$ & $\begin{array}{c}0.31^{* * *} \\
(0.03)\end{array}$ & $\begin{array}{c}0.35^{\star * *} \\
(0.03) \\
0.69^{* \star} \\
(0.28)\end{array}$ & $\begin{array}{c}0.72^{* * \star} \\
(0.03)\end{array}$ & $\begin{array}{c}0.60^{\star \star *} \\
(0.05) \\
0.57^{\star \star \star} \\
(0.13)\end{array}$ & $\begin{array}{c}0.51^{* * *} \\
(0.04)\end{array}$ & $\begin{array}{c}0.52^{* * *} \\
(0.04) \\
0.86^{*} \\
(0.50)\end{array}$ \\
\hline Grant & $\begin{array}{c}0.25^{\star \star *} \\
(0.02)\end{array}$ & $\begin{array}{c}0.25^{\star * *} \\
(0.02)\end{array}$ & $\begin{array}{c}0.40^{* * *} \\
(0.02)\end{array}$ & $\begin{array}{c}0.39^{\star \star *} \\
(0.02)\end{array}$ & $\begin{array}{c}0.19^{* * *} \\
(0.05)\end{array}$ & $\begin{array}{c}0.18^{\star \star *} \\
(0.04)\end{array}$ & $\begin{array}{c}0.40^{* \star *} \\
(0.09)\end{array}$ & $\begin{array}{c}0.31^{\star * *} \\
(0.08)\end{array}$ & $\begin{array}{l}0.03^{*} \\
(0.02)\end{array}$ & $\begin{array}{c}0.08^{* * *} \\
(0.02)\end{array}$ & $\begin{array}{c}0.28^{* * *} \\
(0.09)\end{array}$ & $\begin{array}{l}0.21^{\star *} \\
(0.10)\end{array}$ \\
\hline Depend & $\begin{array}{c}-0.006^{\star * \star} \\
(0.001)\end{array}$ & $\begin{array}{c}-0.007^{\star \star \star} \\
(0.001)\end{array}$ & $\begin{array}{c}0.002 \\
(0.002)\end{array}$ & $\begin{array}{c}0.003 \\
(0.002)\end{array}$ & $\begin{array}{c}0.006 \\
(0.003)\end{array}$ & $\begin{array}{c}0.004 \\
(0.003)\end{array}$ & $\begin{array}{c}0.005 \\
(0.007)\end{array}$ & $\begin{array}{c}0.003 \\
(0.007)\end{array}$ & $\begin{array}{l}0.003^{*} \\
(0.002)\end{array}$ & $\begin{array}{l}0.004^{*} \\
(0.002)\end{array}$ & $\begin{array}{c}0.004 \\
(0.007)\end{array}$ & $\begin{array}{l}0.0003 \\
(0.007)\end{array}$ \\
\hline Denspop & $\begin{array}{l}0.004^{* * *} \\
(0.001)\end{array}$ & $\begin{array}{l}0.004^{* *} \\
(0.002)\end{array}$ & $\begin{array}{l}-0.002 \\
(0.002)\end{array}$ & $\begin{array}{l}-0.002 \\
(0.002)\end{array}$ & $\begin{array}{c}0.003 \\
(0.002)\end{array}$ & $\begin{array}{l}0.004^{*} \\
(0.002)\end{array}$ & $\begin{array}{c}0.004 \\
(0.003)\end{array}$ & $\begin{array}{c}0.005 \\
(0.003)\end{array}$ & $\begin{array}{c}0.0007 \\
(0.0005)\end{array}$ & $\begin{array}{c}0.003 \\
(0.002)\end{array}$ & $\begin{array}{c}0.003 \\
(0.002)\end{array}$ & $\begin{array}{c}0.005 \\
(0.003)\end{array}$ \\
\hline $\begin{array}{l}\text { Observations } \\
R \text {-squared }\end{array}$ & $\begin{array}{c}5,508 \\
0.93\end{array}$ & $\begin{array}{c}5,508 \\
0.93\end{array}$ & $\begin{array}{c}5,508 \\
0.90\end{array}$ & $\begin{array}{c}5,508 \\
0.90\end{array}$ & 4,670 & 4,670 & 5,225 & 5,225 & 4,948 & 4,948 & 4,947 & 4,947 \\
\hline $\begin{array}{l}\text { Municipalities } \\
\text { AR1 }\end{array}$ & & & 278 & 278 & $\begin{array}{c}278 \\
-10.67\end{array}$ & $\begin{array}{c}278 \\
-11.21\end{array}$ & $\begin{array}{c}278 \\
-12.46\end{array}$ & $\begin{array}{c}278 \\
-12.62\end{array}$ & $\begin{array}{c}278 \\
-10.48\end{array}$ & $\begin{array}{c}278 \\
-8.31\end{array}$ & $\begin{array}{c}278 \\
-10.92\end{array}$ & $\begin{array}{c}278 \\
-10.95\end{array}$ \\
\hline$p$-value & & & & & 0.00 & 0.00 & 0.00 & 0.00 & 0.00 & 0.00 & 0.00 & 0.00 \\
\hline$A R 2$ & & & & & 0.57 & 0.47 & 0.17 & -1.13 & -0.49 & -2.00 & -0.28 & -0.48 \\
\hline$p$-value & & & & & 0.57 & 0.64 & 0.87 & 0.26 & 0.63 & 0.05 & 0.78 & 0.63 \\
\hline$A R 3$ & & & & & -0.02 & 0.10 & 0.11 & 0.27 & -0.45 & 1.62 & -0.46 & -0.50 \\
\hline$p$-value & & & & & 0.98 & 0.92 & 0.91 & 0.79 & 0.65 & 0.11 & 0.65 & 0.62 \\
\hline Hansen & & & & & 8.33 & 10.13 & 5.14 & 15.15 & 6.30 & 105.4 & 35.26 & 33.87 \\
\hline$p$-value & & & & & 0.14 & 0.34 & 0.40 & 0.18 & 0.39 & 0.11 & 0.11 & 0.17 \\
\hline$D F$ & & & & & 5 & 9 & 5 & 11 & 6 & 88 & 26 & 27 \\
\hline
\end{tabular}

Sources: INE, DGAL, SI (several years).

Notes: Robust standard errors in parenthesis. Significance level for which the null hypothesis is rejected: ${ }^{\star \star \star} 1 \%$, ${ }^{\star \star} 5 \%$ and ${ }^{*} 10 \%$. GMM stands for GMM system estimation; two-step estimation results are presented. $A R(1), A R(2)$ and $A R(3)$ refer to first, second and third order autocorrelation tests. DF stands for degrees of freedom. In each model the dependent variable corresponds to D.Variable. GMM-sys estimations for total, capital, current and investment expenditures include, respectively, fourth, second, third and third order lags of the dependent variable. 
Table 3 - Estimation results for different weighting matrices

\begin{tabular}{|c|c|c|c|c|c|}
\hline & (1) & (2) & (3) & $(4)$ & $(5)$ \\
\hline Weighting Matrix & & Binary: $W^{0}$ & & $\mathrm{~W}^{50}$ & $W^{100}$ \\
\hline Model & OLS & FE & GMM-Sys & GMM-Sys & GMM-Sys \\
\hline$G_{i t-1}$ & $\begin{array}{c}0.66^{* * *} \\
(0.03)\end{array}$ & $\begin{array}{c}0.30^{* * *} \\
(0.02)\end{array}$ & $\begin{array}{c}0.35^{* * *} \\
(0.04)\end{array}$ & $\begin{array}{c}0.36^{* * *} \\
(0.04)\end{array}$ & $\begin{array}{c}0.35^{\star * *} \\
(0.04)\end{array}$ \\
\hline$W G_{j t}$ & $\begin{array}{c}0.09^{* \star *} \\
(0.02)\end{array}$ & $\begin{array}{l}0.13^{\star \star \star} \\
(0.02)\end{array}$ & $\begin{array}{l}0.22^{* *} \\
(0.09)\end{array}$ & $\begin{array}{l}0.33^{\star \star *} \\
(0.11)\end{array}$ & $\begin{array}{l}0.41^{* \star *} \\
(0.15)\end{array}$ \\
\hline Grant & $\begin{array}{c}0.24^{* * *} \\
(0.02)\end{array}$ & $\begin{array}{c}0.39^{* * *} \\
(0.02)\end{array}$ & $\begin{array}{l}0.13^{* *} \\
(0.05)\end{array}$ & $\begin{array}{l}0.10^{\star} \\
(0.06)\end{array}$ & $\begin{array}{l}0.13^{* *} \\
(0.05)\end{array}$ \\
\hline Depend & $\begin{array}{c}-0.007^{* \star *} \\
(0.001)\end{array}$ & $\begin{array}{c}0.002 \\
(0.002)\end{array}$ & $\begin{array}{l}0.02^{* \star *} \\
(0.004)\end{array}$ & $\begin{array}{l}0.02^{\star \star *} \\
(0.004)\end{array}$ & $\begin{array}{l}0.02^{* \star \star} \\
(0.004)\end{array}$ \\
\hline denspop & $\begin{array}{l}0.004^{\star *} \\
(0.002)\end{array}$ & $\begin{array}{l}-0.002 \\
(0.002)\end{array}$ & $\begin{array}{c}0.002 \\
(0.002)\end{array}$ & $\begin{array}{c}0.003 \\
(0.002)\end{array}$ & $\begin{array}{c}0.003 \\
(0.002)\end{array}$ \\
\hline $\begin{array}{l}\text { Observations } \\
\mathrm{R}^{2}\end{array}$ & $\begin{array}{c}5,508 \\
0.93\end{array}$ & $\begin{array}{c}5,508 \\
0.90\end{array}$ & 5,508 & 5,508 & 5,508 \\
\hline Municipalities & & 278 & 278 & 278 & 278 \\
\hline $\mathrm{AR}(1)$ & & & -12.04 & -12.05 & -12.17 \\
\hline$p$-value & & & 0.00 & 0.00 & 0.00 \\
\hline $\mathrm{AR}(2)$ & & & 1.09 & 0.91 & 0.96 \\
\hline$p$-value & & & 0.27 & 0.36 & 0.34 \\
\hline Hansen test & & & 3.76 & 3.56 & 3.09 \\
\hline$p$-value & & & 0.59 & 0.61 & 0.69 \\
\hline DF & & & 5 & 5 & 5 \\
\hline
\end{tabular}

Sources: INE, DGAL, SI (several years).

Notes: Robust standard errors in parenthesis. Significance level for which the null hypothesis is rejected: ${ }^{* *} 1 \%,{ }^{* *} 5 \%$ and ${ }^{*} 10 \%$. GMM-Sys estimations present two-step results. $A R(1)$ and $A R(2)$ refer to first and second order autocorrelation tests. DF stands for degrees of freedom. In each model the dependent variable is Total Expenditures. 
Table 4 - Estimation results for some investment components

\begin{tabular}{|c|c|c|c|c|}
\hline \multirow[b]{2}{*}{ D. Variable } & \multirow[t]{2}{*}{ OLS } & \multirow[t]{2}{*}{ FE } & \multicolumn{2}{|c|}{ GMM-Sys } \\
\hline & & & Coeff. & Htest \\
\hline 1. Acquisition of land & n.a & n.a. & n.a & n.a \\
\hline 2. Housing & n.a & n.a. & n.a & n.a \\
\hline 3. Transportation material & $\begin{array}{c}0.62 \\
(0.10)^{* * *}\end{array}$ & $\begin{array}{c}0.09 \\
(0.23)\end{array}$ & $\begin{array}{c}0.40 \\
(1.78)\end{array}$ & $\begin{array}{l}23.09 \\
{[17]}\end{array}$ \\
\hline 4. Machinery and equipment & $\begin{array}{c}0.60 \\
(0.08)^{\star \star \star}\end{array}$ & $\begin{array}{c}0.09 \\
(0.22)\end{array}$ & $\begin{array}{c}0.94 \\
(0.15)^{\star * *}\end{array}$ & $\begin{array}{c}112.68 \\
{[97]}\end{array}$ \\
\hline 5. Miscellaneous constructions & $\begin{array}{c}0.13 \\
(0.10)\end{array}$ & $\begin{array}{c}0.51 \\
(0.17)^{\star * *}\end{array}$ & $\begin{array}{c}0.94 \\
(0.46)^{\star *}\end{array}$ & $\begin{array}{c}26.97^{\star} \\
{[18]}\end{array}$ \\
\hline $\begin{array}{l}\text { 5.1. Overpasses, streets and complementary } \\
\text { works }\end{array}$ & $\begin{array}{c}0.43 \\
(0.13)^{\star \star \star}\end{array}$ & $\begin{array}{c}0.26 \\
(0.21)\end{array}$ & $\begin{array}{c}0.28 \\
(0.77)\end{array}$ & $\begin{array}{c}37.55 \\
{[35]}\end{array}$ \\
\hline 5.2. Sewage & $\begin{array}{c}0.28 \\
(0.11)^{\star *}\end{array}$ & $\begin{array}{c}0.26 \\
(0.22)\end{array}$ & $\begin{array}{c}0.86 \\
(0.29)^{\star \star \star}\end{array}$ & $\begin{array}{c}73.61^{*} \\
{[58]}\end{array}$ \\
\hline 5.3. Water treatment and distribution & $\begin{array}{c}0.04 \\
(0.12)\end{array}$ & $\begin{array}{c}0.10 \\
(0.17)\end{array}$ & $\begin{array}{c}0.71 \\
(0.50)\end{array}$ & $\begin{array}{c}10.13 \\
{[7]}\end{array}$ \\
\hline 5.4. Rural roads & $\begin{array}{c}0.60 \\
(0.60)^{\star \star \star}\end{array}$ & $\begin{array}{c}0.51 \\
(0.23)^{* *}\end{array}$ & $\begin{array}{c}0.89 \\
(0.30)^{* \star *}\end{array}$ & $\begin{array}{c}41.94 \\
{[40]}\end{array}$ \\
\hline 5.5. Infrastructures on solid waste treatment & n.a & n.a. & n.a & n.a \\
\hline 5.6. Other Miscellaneous Constructions & $\begin{array}{l}0.25 \\
(0.12)^{* *}\end{array}$ & $\begin{array}{c}0.24 \\
(0.21)\end{array}$ & $\begin{array}{l}0.60 \\
(0.26)^{\star *}\end{array}$ & $\begin{array}{c}18.25^{*} \\
{[11]}\end{array}$ \\
\hline 6. Other buildings & $\begin{array}{c}0.02 \\
(0.18)\end{array}$ & $\begin{array}{c}0.34 \\
(0.23)\end{array}$ & $\begin{array}{c}0.15 \\
(0.35)\end{array}$ & $\begin{array}{c}28.67^{*} \\
{[19]}\end{array}$ \\
\hline $\begin{array}{l}\text { 6.1. Sports, recreational and schooling } \\
\text { facilities }\end{array}$ & $\begin{array}{c}0.47 \\
(0.13)^{\star * *}\end{array}$ & $\begin{array}{c}0.55 \\
(0.14)^{* * *}\end{array}$ & $\begin{array}{c}0.78 \\
(0.29)^{* * *}\end{array}$ & $\begin{array}{c}45.86^{*} \\
{[33]}\end{array}$ \\
\hline 6.2. Social equipment & n.a & n.a. & n.a & n.a \\
\hline 6.3. Other Expenditures in Other Buildings & $\begin{array}{c}0.59 \\
(0.17)^{\star \star *}\end{array}$ & $\begin{array}{c}0.88 \\
(0.21)^{* * *}\end{array}$ & $\begin{array}{c}0.86 \\
(0.32)^{\star * \star}\end{array}$ & $\begin{array}{c}36.04 \\
{[28]}\end{array}$ \\
\hline 7. Other investments & n.a & n.a. & n.a & n.a \\
\hline
\end{tabular}

Sources: INE, DGAL, SI (several years).

Notes.: Robust standard errors in parenthesis. Hansen test's (H-test) degrees of freedom in brackets. Significance level for which the null hypothesis is rejected: ${ }^{* *} 1 \%,{ }^{* *} 5 \%$ and ${ }^{*} 10 \%$. GMM-Sys estimations present two-step results. In each model the dependent variable corresponds to D. Variable. The reported coefficient and standard error is for the neighbouring variable. Estimations include third order lags of the dependent variable; the exception is the estimation for Sports, recreational and schooling facilities, which includes two lags of the dependent variable. 
Table 5 - Estimation results for yardstick competition models: Estimates using $\mathrm{W}^{\text {all }}$

\begin{tabular}{|c|c|c|c|c|}
\hline & (1) & (2) & (3) & (4) \\
\hline $\begin{array}{l}\text { D. Variable } \\
\text { Model }\end{array}$ & $\begin{array}{c}\text { TotExp } \\
\text { GMM-sys }\end{array}$ & $\begin{array}{c}\text { CapExp } \\
\text { GMM-sys }\end{array}$ & $\begin{array}{c}\text { CurExp } \\
\text { GMM-sys }\end{array}$ & $\begin{array}{c}\text { InvExp } \\
\text { GMM-sys }\end{array}$ \\
\hline$G_{i t-1}$ & $\begin{array}{c}0.40^{* \star *} \\
(0.04)\end{array}$ & $\begin{array}{c}0.34^{* * *} \\
(0.03)\end{array}$ & $\begin{array}{c}0.65^{\star * *} \\
(0.04)\end{array}$ & $\begin{array}{c}0.52^{\star * *} \\
(0.03)\end{array}$ \\
\hline$W G_{\text {it }}$ & $\begin{array}{c}0.60^{* * *} \\
(0.17)\end{array}$ & $\begin{array}{l}0.45^{\star} \\
(0.28)\end{array}$ & $\begin{array}{l}0.28^{*} \\
(0.16)\end{array}$ & $\begin{array}{l}0.85^{\star \star} \\
(0.32)\end{array}$ \\
\hline Mun Election $_{i t}{ }^{*} W G_{i t}$ & $\begin{array}{c}0.02 \\
(0.08)\end{array}$ & $\begin{array}{c}0.20 \\
(0.17)\end{array}$ & $\begin{array}{l}-0.07 \\
(0.12)\end{array}$ & $\begin{array}{l}-0.14 \\
(0.16)\end{array}$ \\
\hline Hansen & 36.09 & 1.16 & 6.22 & 33.21 \\
\hline$p$-value & $0.07^{*}$ & 0.14 & 0.40 & 0.16 \\
\hline DF & 25 & 11 & 6 & 26 \\
\hline
\end{tabular}

Sources: INE, DGAL, SI (several years).

Notes: Robust standard errors in parenthesis. Significance level for which the null hypothesis is rejected: ${ }^{* *} 1 \%,{ }^{* \star} 5 \%$ and ${ }^{*} 10 \%$. GMM stands for Generalized Method of Moments system estimation; two-step estimation results are presented. $A R(1), A R(2)$ and $A R(3)$ refer to first, second and third order autocorrelation tests. DF stands for degrees of freedom. In each model the dependent variable corresponds to D.Variable. Estimations for total, capital, current and investment expenditures include respectively fourth, second, third and third order lags of the dependent variable. 
Table 6 - Estimation results using weights based on population density

\begin{tabular}{lcccc}
\hline \hline D. Variable & $(1)$ & $(2)$ & $(3)$ & $(4)$ \\
Model & $\begin{array}{c}\text { TotExp } \\
\text { GMM-sys }\end{array}$ & $\begin{array}{c}\text { CurrentExp } \\
\text { GMM-sys }\end{array}$ & $\begin{array}{c}\text { CapExp } \\
\text { GMM-sys }\end{array}$ & $\begin{array}{c}\text { InvExp } \\
\text { GMM-sys }\end{array}$ \\
\hline Population Density & & & & \\
& & & & \\
$\mathrm{G}_{\mathrm{it}-1}$ & & & & \\
$\mathrm{~W}^{\mathrm{PD}} \mathrm{G}_{\mathrm{it}}$ & $0.44^{* * *}$ & $0.69^{* * *}$ & $0.33^{* * *}$ & $0.53^{* * *}$ \\
& $(0.04)$ & $(0.04)$ & $(0.04)$ & $(0.04)$ \\
Hansen & 0.08 & 0.02 & 0.06 & $0.33^{\star *}$ \\
$\mathrm{p}$-value & $(0.06)$ & $(0.05)$ & $(0.13)$ & $(0.14)$ \\
$\mathrm{DF}$ & & & & \\
\hline \hline
\end{tabular}

Sources: INE, DGAL, SI (several years).

Notes: Robust standard errors in parenthesis. Significance level for which the null hypothesis is rejected: ${ }^{* *} 1 \%,{ }^{* \star} 5 \%$ and ${ }^{*} 10 \%$. GMM stands for Generalized Method of Moments system estimation; two-step estimation results are presented. $A R(1), A R(2)$ and $A R(3)$ refer to first, second and third order autocorrelation tests. DF stands for degrees of freedom. In each model the dependent variable corresponds to D.Variable. Estimations for total, current, capital and investment expenditures include, respectively, fourth, third, second and third order lags of the dependent variable. 